Föremål, som befunnit sig länge i svensk ägo och har blivit en del av den svenska bildningshistorien bör stanna i landet, eftersom det skulle skapa stor förvirring för forskningen om åratal av katalogisering och referenser i litteraturen skulle förändras genom ett återbördande. Ur forskningssynpunkt är viktigt att hålla ihop samlingar och med modern informationsteknik har tillgängligheten ökat oavsett var föremålen är fysiskt placerade. En annan aspekt är, att det kan vara svårt att garantera att kraven på god vård och förvaring av föremålen uppfylls.
Det är också många gånger omöjligt att återlämna föremål till den ursprunglige ägaren. Men som framgår av mina exempel går det att göra undantag. Sverige har faktiskt återlämnat föremål genom gåvor, kopior och depositioner.

Avdelningschef Monika Minnhagen-Alvsten, Adr. Riksantikvarieämbetet, Box 5405 , SE-114 84 Stockholm

Fax: +4686607284

E-mail:monika.minnhagen-alvsten@raa.se

\section{NÅGRA SLUTORD...}

- Återförandefrågorna visar tydligt att vi arbetar på två arenor, en offentlig och en inommuseal. Den ena styrs av krafter i samhället som kan tyckas tillfälliga, men som är uttryck för tidsandan. Den andra kan upplevas som tryggare, där vi arbetar med långsiktiga mål samtidigt som vi dock måste ägna våra krafter åt enskilda, ofta små, frågor. I just återförandesammanhanget skymtar museets engagerande och stora betydelse.

- Vi, museimän, vill ladda föremålen med betydelse, men det är viktigt att vi inser att det är andra som tar över tolkningen och utnyttjar våra utsagor. Hur vi förhåller oss till föremålen spelar större roll än vi gärna tror. Vi har sett hur enskilda museimän genom sin person varit helt avgörande för hur återförandefrågor lösts. Det gäller då att vi kan hantera våra egna, djupa känslor

- Vi måste också se oss i samhället och tänka över hur vi kan bidra till samhällsnyttan med det rika kulturarvet i våra händer. Här handlar det om hur vi arbetar strategiskt med politiker och allmänhet, där det kan gälla att rätt hantera de möjligheter till finansiering som uppstår när en fråga hamnat i sökarljuset. När saken inte får uppmärksamhet utan enbart är intermuseal blir läget ett annat.

- Föredragen har understrukit att vi har ett kulturarv, som binder oss samman - alla har vi känt gemenskap med Snorre i Reykholt! Skandinaviska museiförbundet kan lyfta fram och belysa just nordiska övergripande frågor. Ofta kan vi bättre se oss själva genom en nordisk granne som är lik och ändå - olik. Själv har jag genom åren fått mycken inspiration genom det nordiska samarbetet och även fătt pröva hur det håller internationellt.

- I föredragen har framhävts vikten av fortsatt kunskapsutbyte och forskningssamarbete. Det gäller att efter ett återförande vidmakthålla och aktivt arbeta för utbytet. Här kan de två Arnamagneanska instituten vara en förebild. Kulturarvet ägs av alla gemensamt.

Nanna Hermansson, svenska sektionens ordforande 